
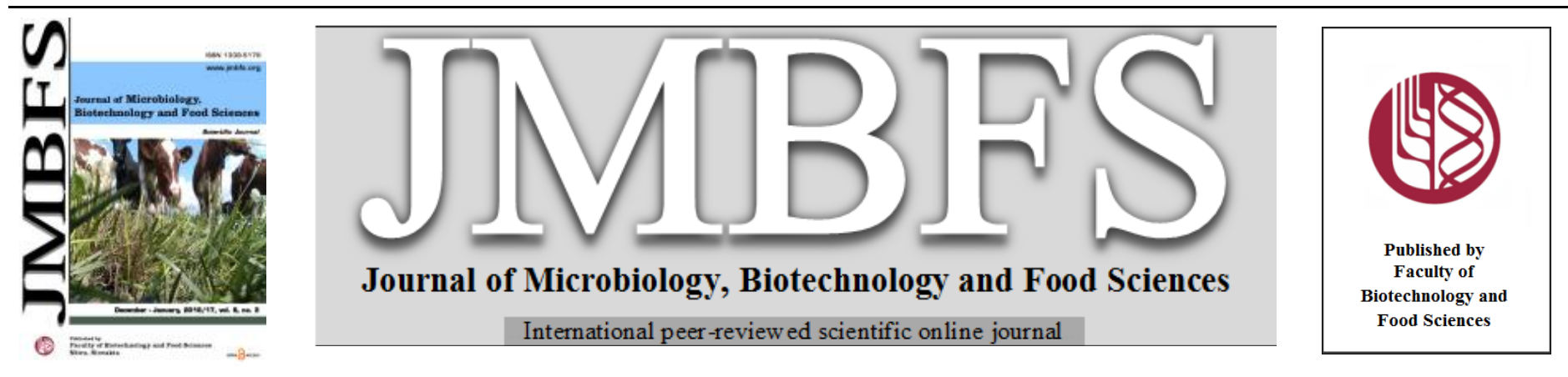

\title{
ISOLATION AND CHARACTERIZATION OF PROBIOTIC LACTOBACILLUS SPECIES FROM CURD SAMPLES AND EVALUATION OF THEIR ANTAGONISTIC POTENTIAL
}

\author{
Satyajit Satapathy ${ }^{1 *}$, Balaram Mohapatra $^{2}$, Himanshu Shekhar Duttal and Tarun Tapan Tripathy ${ }^{l}$
}

\author{
Address(es): \\ ${ }^{1}$ Department of Microbiology, Centre for Post Graduate Studies (CPGS), ' Orissa University of Agriculture and Technology, Bhubaneswar (Odisha) - 753001, India. \\ ${ }^{2}$ Department of Biotechnology, ${ }^{2}$ Indian Institute of Technology, Kharagpur (West Bengal) - 721302, India.
}

*Corresponding author: satyajitmicromania@gmail.com

doi: $10.15414 /$ jmbfs.2016/17.6.3.867-873

\section{ARTICLE INFO}

Received 13. 12. 2015

Revised 7. 6. 2016

Accepted 30. 7. 2016

Published 1. 12. 2016

Regular article open $O$ access

\begin{abstract}
Fermentative milk products with probiotic properties escalate as a necessary substitution in human and animal feed consumption for well being of the gut microflora. One of the key aspects is being the reducing the population of pathogens and production of vitamins. The live bacterial community of these fermented foods can reduce the effect of antibiotics and increase the immune function. Ten beneficial Lactobacillus sp. were isolated from two local curd samples and characterized in terms of morphological, biochemical, molecular and physiological characteristics. Antagonistic potential of all the isolates were studied against enteric pathogens; Escherichia coli, Salmonella typhi, Shigella boydii and Enterococcus faecalis. All are gram-positive rod of non-endospore forming ability with $\mathrm{pH}$ tolerance range of 5-8, $\mathrm{NaCl}$ tolerance limit of $5 \%(\mathrm{w} / \mathrm{v})$. A wide spectrum of antibiotic resistance was noticed for all the isolates. Almost all isolates showed antagonism against $E$. coli and $S$. typhi followed by $S$. boydii and E. faecalis and strains OC 3 and $\mathrm{KC} 2$ were found to be the best potential candidates. Bacteriocin extract showed a little difference denoting OC3 and $\mathrm{KC} 2$ as well as OC5 as effective against all the enteric pathogens. 16S rRNA gene sequence analysis and phylogenetic characterization revealed the taxonomic affiliation of the strain OC3 and KC2 to L. brevis ATCC 14869 (T) and L. paraplantarum DSM 10667 (T) showing 99\% of sequence similarity with high phylogenetic lineage towards probiotic Lactobacillus type strains. These strains can be used as potential probiotic agents as starter inoculum for the fermented foods and reducing disease incidence caused by enteric pathogens in human and help in dropping antibiotic consumption.
\end{abstract}

Keywords: Probiotics, Lactobacillus sp., antagonistic activity, bacteriocin, phylogeny

\section{INTRODUCTION}

Fermented foods and milk products with health benefits are known to human kind since ancient times and the relationship has been investigated for long years (Pyar and Peh, 2014). Consumption of active microorganisms (probiotics) through fermented food products has been centre of attraction among all. Probiotics are the active microorganisms which when administered orally in required amount confer health benefits (Asha and Gayatri, 2012). Recent research has been focused on exploring potential probiotics candidate in the form of fermented food like yoghurt, cheese, pudding, ice-cream, sausages and other milk products to replace antibiotic based drug intake (Chan et al., 2000). Because, recent trend of emergence of antibiotic resistant pathogenic strains with multiple drug resistance (MDR) capacity have become a serious threat to human health (Ahmed, 2013). As a result, there is increasing probability of gastrointestinal infection and high mortality rate. According to World Health Organization (WHO), enteric infection is the fifth leading cause of death among all age groups worldwide and the causal agents are the enteric pathogens; Escherichia sp., Shigella sp., Vibrio sp., Salmonella sp., Staphylococcus sp., etc. So, probiotics with therapeutic use has become a fast alternative to reduce the antibiotic consumption and subsequent enteric infection (Ballal and Shivananda, 2002). As Lactobacillus sp (Lactic acid bacteria; LAB) are one of the group of intestinal microflora as a healthy partner and symbionts causing various health benefits, researchers have paid attention to these microbes by using it in fermented foods as probiotics.

Lactic acid bacteria (LAB) is a group of acid producing bacteria used in the food industry and making starter culture for dairy products (Gharaei-Fathabad and Eslamifer, 2011). The proper selection and balance for starter culture is critical for the manufacture of fermented products of desirable texture and flavor. Members of this group include gram-stain-positive, non-spore forming, cocci or rods with catalase negative fastidious organism belonging to family Lactobacillaceae of phylum Firmicutes (Felis and Dellagio, 2015). These organisms have been considered as "Generally Recognized as Safe" (GRAS) due to their positive impacts on health in the form of probiotics (Forouhandeh $\boldsymbol{e t}$ al.,
2010). They are known to produce antagonistic substances such as hydrogen peroxide, carbon dioxide and bacteriocin other than organic acids (lactate and acetate) against food borne pathogens and spoilage microorganism and hence extend the shelf life and safety of the products (Durne et al., 2001; Chowdhury et al., 2012). Bacteriocin of $\mathrm{LAB}$ is most promising extracellular bactericidal product (mostly proteins) that is secreted by the LAB (Tagg et al., 1976; Holzapfel et al., 1995). Bacteriocins produced by LAB are considered as safer natural or bio-preservatives, as they are degraded by the proteases in gastrointestinal tract unlike traditional antibiotics. They can also reduce the use of chemical preservatives in foods (Cleveland et al., 2001). On the basis of the protein structure, bacteriocin constitutes a heterogeneous group of small peptides of high molecular weight protein or protein complexes. The inhibition spectrum of bacteriocin produced by LAB towards gram positive bacteria varies widely but is most confined to closely related species of the producing bacteria and gram negative members (Puniya et al., 2012). Animal studies and human clinical research have shown lactobacilli being able to accelerate recovery from a range of intestinal conditions, and preventing infection (Mobarez et al., 2008). The foremost mechanism of antagonistic property of $\mathrm{LAB}$ is attributed to decrease $\mathrm{pH}$ by producing acid and production of other primary and secondary antimicrobial metabolites as a result of fermentation process. Most of the probiotics lactobacilli in human foods are supplied in highly concentrated forms containing more than $10^{10} \mathrm{CFU} / \mathrm{g}$ (Parada et al., 2007). There are different ways by which lactobacilli may produce probiotic effects such as; acidifying the intestine, attaching to the intestinal lining, producing various anti-microbial substances, competing with pathogens for nutrients, modulating the host immune system and alleviating lactose intolerance etc (Asha and Gayatri, 2012). At the time of writing, there are 214 species of Lactobacillus with quite a broad range of characteristics, but only a few have been used in probiotics products, including: Lactobacillus acidophilus, Lactobacillus casei, Lactobacillus crispatus, Lactobacillus delbrueckii, Lactobacillus johnsonii, Lactobacillus paracasei, Lactobacillus plantarum, Lactobacillus rhamnosus and Lactobacillus salivarius (www.bacterio.net/LPSN/Lactobacillus). 
Considering all the research need and future implications of the potential Lactobacillus $s p$. in different fermented food industries and human health sector, the present study was conducted to isolate and characterize indigenous Lactobacillus sp. from the curd samples available in the local market of Bhubaneswar, Odisha, India. Subsequently their growth behavior, physiological characteristics and in-vitro antagonistic activity was assessed against some enteric pathogens. The best potential strains showing maximum activity were selected for identification through 16S rRNA gene sequencing and its evolutionary relationship with other Lactobacillus sp. members.

\section{MATERIALS AND METHODS}

\section{Sample collection}

Two curd samples of different variety available in the local market of Bhubaneswar, Odisha, India were collected in a sterile polypropylene vials after flushing the vials twice with the same samples inside laminar air flow in the laboratory. The $\mathrm{pH}$ of the samples was checked with help of $\mathrm{pH}$ electrode by diluting it with sterile distilled water in a ratio of 1:2. The samples were stored at $4^{\circ} \mathrm{C}$ for further processing and isolation of Lactobacillus sp.

\section{Isolation, identification and characterization of Lactobacillus species}

Lactic acid bacterial strains were isolated from the curd samples using deMan Rogosa Sharpe (MRS) plates acidified with $1 \mathrm{~N} \mathrm{HCl}$ to adjust the $\mathrm{pH}$ from 6.7 to 4.5 to inhibit the growth of other fastidious organisms. 1 gram of curd sample suspended in $9 \mathrm{~mL}$ sterile normal saline solution, shaken at $150 \mathrm{rpm}$ for $15 \mathrm{~min}$, diluted serially by 10 fold dilution and $0.1 \mathrm{~mL}$ aliquots of appropriate dilutions were plated on MRS plates, and incubated anaerobically in anaerobic gas jar at $37^{\circ} \mathrm{C}$ for $3-5$ days. Based on colony morphology and pigmentation, individual colonies were picked up and purified by repeated sub culturing on the same medium. The cultured isolates were characterized on the basis of gram staining, endospore formation ability, and biochemical characteristics as described in Bergey's Manual of Determinative Bacteriology (Holt et al., 1994). Biochemical characterization was performed in terms of assimilation of different sugars (arabinose, cellobiose, esculin, D-fructose, galactose, maltose, mannose, melibiose, raffinose, rhamnose, sorbitol, sucrose, trehalose and xylulose), Production of $\mathrm{H}_{2} \mathrm{~S}$, gas and enzymes (such as amylase, urease, catalase, and nitrate reductase), assimilation of sulphate and iron and growth in anaerobic condition.

\section{Tolerance to different sodium chloride $(\mathrm{NaCl})$ concentrations and $\mathrm{pH}$}

For determination of $\mathrm{NaCl}$ tolerance, all the isolates were grown in MRS broth amended with different concentrations of $\mathrm{NaCl}(1-8 \%[\mathrm{w} / \mathrm{v}]) .1 \%(\mathrm{v} / \mathrm{v})$ of the freshly grown overnight culture of the isolates were inoculated into the test tube containing MRS broth medium and incubated at $30^{\circ} \mathrm{C}$ for $48 \mathrm{~h}$. Growth was checked using a UV-VIS spectrophotometer (Cary 50, Varian, USA) by measuring optical density (OD) at $600 \mathrm{~nm}$. Optimum $\mathrm{pH}$ for the growth of the isolates was determined by inoculating $1 \%(\mathrm{v} / \mathrm{v})$ of the overnight culture of the isolates into MRS broth with varying $\mathrm{pH}$ ranging from 3.0 to 11.0. The acidic range of the $\mathrm{pH}$ was set by adding $1 \mathrm{~N} \mathrm{HCl}$ and alkaline range was achieved by adding $1 \mathrm{~N} \mathrm{NaOH}$ and measuring $\mathrm{pH}$ with $\mathrm{pH}$ probe electrode. The inoculated broths were then incubated at $30^{\circ} \mathrm{C}$ for $48 \mathrm{~h}$. Growth of the bacterial isolates was measured as mentioned above. Growth with optical density $<0.5$ termed as no growth, $>0.5$ as moderate growth and $>1.0$ as luxuriant growth.

\section{Determination of antibiotic susceptibility of the isolates}

Antibiotic susceptibility test was carried out by Kirby Bauer disc diffusion method on Mueller Hinton agar (Bauer et al., 1966). The antibiotics(each $30 \mu \mathrm{g}$ ) discs (Hi-Media, India); amikacin, amoxicillin, amphotericin-B, ampicilin, azithromycin, bacitracin, cefactam, cefepime, cefixime, cephadroxil, cephataxime, chloramphenicol, erythromycin, gatifloxacin, gentamicin, kanamycin, methicillin, neomycin, norfloxacin, penicillin-G, polymixin-B, rifampicin, streptomycin, tetracycline and vancomycin were placed on lawn culture of bacterial strains on Muller-Hilton agar medium and incubated at $30^{\circ} \mathrm{C}$ for $24 \mathrm{~h}$. The zone of inhibition around the well confirmed strain's inability to grow in presence of antibiotics (sensitive or susceptible) and no zone of inhibition indicated resistance against those antibiotics. All experiments were performed in triplicates.

\section{Production of crude bacteriocin}

The isolates from the curd sample were tested for their ability to produce bacteriocin. The isolates maintained in MRS agar were inoculated in to MRS broth and incubated at $37^{\circ} \mathrm{C}$ for 48 hours. Cells were separated by centrifugation at $5000 \mathrm{rpm}$ for 10 minutes. The cell free supernatant was passed through 0.45 $\mu \mathrm{m}$ membrane filter and the resultant filtrate containing bacteriocin was evaluated for antimicrobial activity.
Test for antagonistic effect of the isolated strains/extract on enteric pathogens

All the isolated LAB strains and their bacteriocin extract were subjected to screening for antagonistic activity against indicator pathogens by agar well diffusion method and spot-on-the-lawn technique. E. faecalis, S. boydii, E. coli and $S$. typhi pathogenic strains were used as indicator organisms. The culture of the indicator strains were prepared by pouring $1 \mathrm{~mL}$ of the inoculum onto MHA plates to completely cover the surface of the agar. Six mm diameter wells were produced by punching into the agar using sterilized well puncher. $20 \mu \mathrm{L}$ of each $\mathrm{LAB}$ strain inoculum $\left(1 \times 10^{3-4} \mathrm{CFU} / \mathrm{mL}\right)$ was placed into each well carefully with sterile pipette. In case of bacteriocin extract, $20 \mu \mathrm{L}$ of the aliquot was poured into each well. The zone of inhibition was visualized around the wells were recorded after incubating the plates for $48 \mathrm{~h}$ at $37^{\circ} \mathrm{C}$. In the spot-on-thelawn technique, $1 \mathrm{~mL}$ of each LAB strain inoculum added to $15 \mathrm{~mL}$ of the MRS medium, plated and incubated at $37^{\circ} \mathrm{C}$ for $24 \mathrm{~h}$. After incubation, plates were overlaid with $10 \mathrm{~mL}$ of MHA semi-solid agar $(0.8 \mathrm{~g} / 100 \mathrm{~mL})$ and inoculated with $10^{4-5} \mathrm{CFU} / \mathrm{mL}$ of indicator organisms. The plates were then incubated at $37^{\circ} \mathrm{C}$ for $24 \mathrm{~h}$ for visualization of inhibition zone around the spots. Spot showing clear zone was considered a positive antagonistic effect. The strains with best antagonistic effect in all the conditions were selected for identification by $16 \mathrm{~S}$ rRNA gene sequencing and phylogenetic analysis.

\section{Amplification of 16S rRNA gene and Phylogenetic analysis}

Genomic DNA of the selected strains was isolated from 24h grown culture in MRS broth by using phenol/chloroform extraction followed by purification with Isopropanol. Partial sequence of the 16S rRNA gene was amplified from the genomic DNA by PCR thermal cycler by using universal eubacterial primers: $27 \mathrm{~F} / 1492 \mathrm{R}$ with an initial denaturation step at $95^{\circ} \mathrm{C}$ for $10 \mathrm{~min}$, followed by 35 cycles of $94^{\circ} \mathrm{C}$ for $1 \mathrm{~min}, 58^{\circ} \mathrm{C}$ for $1 \mathrm{~min}, 72^{\circ} \mathrm{C}$ for $2 \mathrm{~min}$ and a final extension at $72^{\circ} \mathrm{C}$ for $5 \mathrm{~min}$. Gel slices containing the amplicons DNA were cut under a UV Trans-illuminator and transferred into an eppendorf tube for gel extraction. The PCR amplicons were gel purified using Qiaquick PCR purification kit (Qiagen, Germany) according to manufacturer's instructions and sequenced. The obtained sequence chromatogram was compared with sequences available within the NCBI database (http://www.ncbi.nih.gov) by BLASTn search using FASTA sequence. Basing on the maximum sequence homology, sequences of the most closely related species were retrieved from RDP database and all of the sequences were aligned by using ClustalW (http://www.ebi.ac.uk/clustalw/). Pair wise evolutionary distances were calculated using the algorithm of Jukes and Cantor and the phylogenetic dendrogram were constructed using the neighborjoining (NJ) method with bootstrap analysis based on 1000 replications using the program MEGA (version 5.1). For evaluation of robust phylogenetic relationship, the obtained nucleotide sequences were also checked for its identification through EzTaxon server (http://www.ezbiocloud.net/eztaxon) with bacterial type strains of validly described taxa, where the ambiguous bases were removed from the assembled sequences and searched against the cultured species for maximum sequence similarity (\% identity).

\section{Growth behavior study of the selected bacterial strains}

In this study, two of the selected isolated strains; $\mathrm{OC} 3$ and $\mathrm{KC} 2$ were chosen for study of growth behavior and kinetics. Pure cultures of the each bacterial strain (single colony from the MRS agar plate) were transferred to $5 \mathrm{ml}$ of the MRS broth for preparation of starter inoculum by incubating at $37^{\circ} \mathrm{C}$ for $24 \mathrm{~h} .1 \%(\mathrm{v} / \mathrm{v})$ of freshly grown culture of each strain (OD $570 \mathrm{~nm} \sim 0.5-0.6$ ) was transferred to sterile $250 \mathrm{~mL}$ Erlenmeyer flask containing $100 \mathrm{~mL}$ of the MRS broth. One flask with Escherichia coli (a laboratory strain) was taken as internal control, while medium without any inoculum was used as blank. All the flasks were incubated in a shaker incubator at $37^{\circ} \mathrm{C}$ for $24 \mathrm{~h}$. Growth was checked by measuring optical density of the culture with the spectrophotometer at $570 \mathrm{~nm}$ over the period of time in interval. Specific growth rate $(\mu)$ of each strain was calculated by following equation:

$$
\frac{\log \mathrm{Nt}-\log \mathrm{No}}{\mathrm{t} 1-\mathrm{t} 0}=\frac{\mu}{2.303}
$$

Where, $\mathrm{Nt}=$ Absorbance at initial log phase of the growth $\mathrm{N}_{0}=$ Absorbance at final log phase of the growth $\mathrm{t}_{1}-\mathrm{t}_{0}=$ time difference from $\mathrm{Nt}$ to $\mathrm{N}_{0}$

\section{RESULTS AND DISCUSSION}

Fermented milk products have become a potential carrier of antimicrobial compounds and serve as suitable alternative of antibiotic consumption. Mostly dairy products with probiotics nature has become as an example of classical food with nutritive value (Kyriacou et al., 2008). Recent research has been focused on exploring suitable probiotics candidate contained within fermented dairy products 
such as curd, yoghurt etc for their antagonistic property against enteric pathogens. The purpose of this study was to isolate and characterize potential probiotic Lactobacillus species from curd samples available in the local market of Bhubaneswar, Odisha, India and to explore their antagonistic activity against enteric pathogens. Further, to confirm their taxonomic affiliation, 16S rRNA gene sequence was analyzed and phylogenetic relationship was inferred.

\section{Sample collection and analysis}

Two curd samples from the local market was procured and designated as OC and $\mathrm{KC}$. Both the samples were found to be acidic in nature with average $\mathrm{pH}$ value of 4.5-5.5. Samples were further analyzed for isolation of Lactobacillus species.

\section{Isolation, identification and characterization of Lactobacillus species}

Isolation of Lactobacillus strains has been accomplished by using Lactobacillus selective medium MRS agar. A total of 10 bacterial isolates were isolated from both the curd samples based on their colony characteristics and pigmentation on MRS plates. All the isolates were designated as OC1 to OC5 (5 colonies from sample OC) and $\mathrm{KC} 1$ to KC5 (5 colonies from sample KC). The morphological and biochemical characterization of the isolates were carried out and the results are mentioned in the table1. All the isolates were found to be gram positive (+ve) bacilli without ability to formation of endospore. Catalase, urease, amylase, production of $\mathrm{H}_{2} \mathrm{~S}$, nitrate reduction and motility tests were found to be negative for all the isolates. Among various carbohydrate used for assimilation, all the isolates assimilated arabinose, cellobiose, fructose, lactose, mellobiose, maltose, mannose, sorbitol, sucrose and trehalose. Out of 10 , nine isolates showed positive response to galactose and rhamnose. Only two of the isolates could able to use esculin and raffinose (Table 1, Fig 1). Interestingly, lactose was found to be used by all, as it is the principal sugar available in the milk and milk products. All the isolates also showed same anaerobic growth pattern. Hence, from the biochemical properties, it was confirmed that all the isolates showed determinative properties of members of Lactobacillus sp. As probiotics bacteria mostly consumed by human being directly by oral administration, they must be tolerant to varying $\mathrm{pH}$ (acidic in the stomach and alkaline in the intestine) and different salt $(\mathrm{NaCl})$ concentration (Davidson, 2003). So, $\mathrm{pH}$ tolerance and temperature tolerance profile were studied for all the isolates (Fig 2). Among all, only two isolates ( $\mathrm{OC} 3$ and $\mathrm{KC} 2$ ) showed tolerance from $\mathrm{pH} 4$ to 9 . Almost all showed luxuriant growth in $\mathrm{pH} 6$ to 8 showing their near neutral growth behavior. $\mathrm{OC} 3$ and $\mathrm{KC} 2$ were found to be most resistant towards acid and basic $\mathrm{pH}$ showing their versatility to resist all $\mathrm{pH}$ condition of gastro-intestinal tract. In the study of salt tolerance profile, all showed almost similar pattern of growth where, $5 \% \mathrm{NaCl}$ was found to be the maximum concentration above which growth was inhibited. $\mathrm{OC} 2, \mathrm{OC} 3, \mathrm{KC} 1$ and $\mathrm{KC} 4$ were the most potent in terms of using $\mathrm{NaCl}$ during their growth.

Table 1 Differential phenotypic characteristics of isolated bacterial strains from curd samples

\begin{tabular}{|c|c|c|c|c|c|c|c|c|c|c|}
\hline \multirow{2}{*}{ Properties } & \multicolumn{10}{|c|}{ Bacterial strains } \\
\hline & $\mathrm{OC} 1$ & $\mathrm{OC} 2$ & OC3 & $\mathrm{OC} 4$ & OC5 & $\mathrm{KC} 1$ & $\mathrm{KC} 2$ & $\mathrm{KC} 3$ & $\mathrm{KC} 4$ & KC5 \\
\hline Gram reaction & $+v e$ & $+\mathrm{ve}$ & $+\mathrm{ve}$ & $+\mathrm{ve}$ & $+\mathrm{ve}$ & $+\mathrm{ve}$ & $+\mathrm{ve}$ & $+\mathrm{ve}$ & $+\mathrm{ve}$ & $+v e$ \\
\hline Shape & Bacilli & Bacilli & Bacilli & Bacilli & Bacilli & Bacilli & Bacilli & Bacilli & Bacilli & Bacilli \\
\hline pH (opt) & $5.5-6.5$ & $5.5-6.5$ & $5.5-6.5$ & $5.5-6.5$ & $5.5-6.5$ & $5.5-6.5$ & $5.5-6.5$ & $5.5-6.5$ & $5.5-6.5$ & $5.5-6.5$ \\
\hline $\mathrm{Temp}\left({ }^{\circ} \mathrm{C}\right)$ & $30-35$ & $30-35$ & $30-35$ & $30-35$ & $30-35$ & $30-35$ & $30-35$ & $30-35$ & $30-35$ & $30-35$ \\
\hline Endospore & -ve & -ve & -ve & -ve & -ve & $-\mathrm{ve}$ & -ve & -ve & $-\mathrm{ve}$ & - ve \\
\hline Catalase & -ve & -ve & -ve & -ve & -ve & -ve & -ve & -ve & $-\mathrm{ve}$ & -ve \\
\hline $\mathrm{H}_{2} \mathrm{~S}$ production & -ve & -ve & $-\mathrm{ve}$ & -ve & $-\mathrm{ve}$ & $-\mathrm{ve}$ & $-\mathrm{ve}$ & $-\mathrm{ve}$ & $-\mathrm{ve}$ & -ve \\
\hline Nitrate reduction & -ve & -ve & -ve & -ve & -ve & -ve & -ve & -ve & -ve & $-\mathrm{ve}$ \\
\hline Starch hydrolysis & -ve & -ve & -ve & -ve & -ve & -ve & -ve & -ve & -ve & -ve \\
\hline Urease & -ve & -ve & -ve & -ve & -ve & -ve & -ve & -ve & $-\mathrm{ve}$ & -ve \\
\hline Mannitol motility & -ve & -ve & -ve & -ve & -ve & -ve & -ve & -ve & -ve & -ve \\
\hline
\end{tabular}

Strains; OC1 to OC5 (from sample 1), KC1 to KC5 (from sample 2), $\mathrm{pH}$ (opt); $\mathrm{pH}$ optimum, Temp $\left({ }^{\circ} \mathrm{C}\right.$ ); Temperature in degree centigrade, $+\mathrm{ve}$; Positive, -ve; Negative.

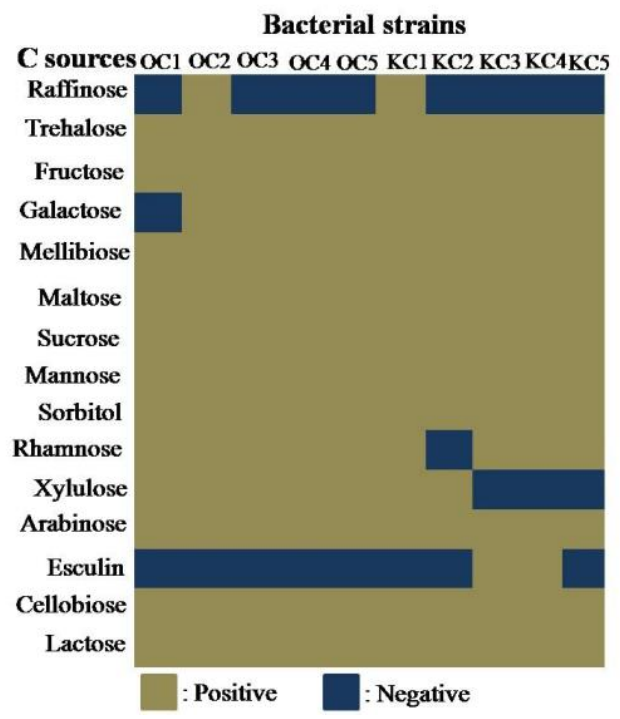

Figure 1 Differential biochemical properties (C source utilization) and their response observed for isolated bacterial strains from curd samples.
Salt conc. ( $\mathrm{NaCl} \%)$

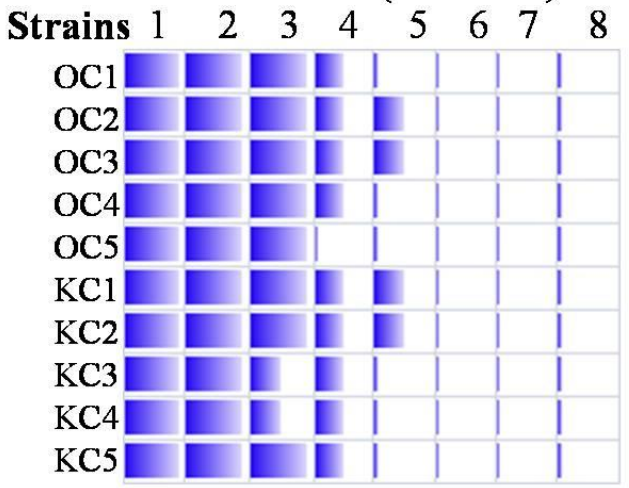

| : Very weakly +ve

I. :Moderately tve

:Highly +ve 


\section{pH range}

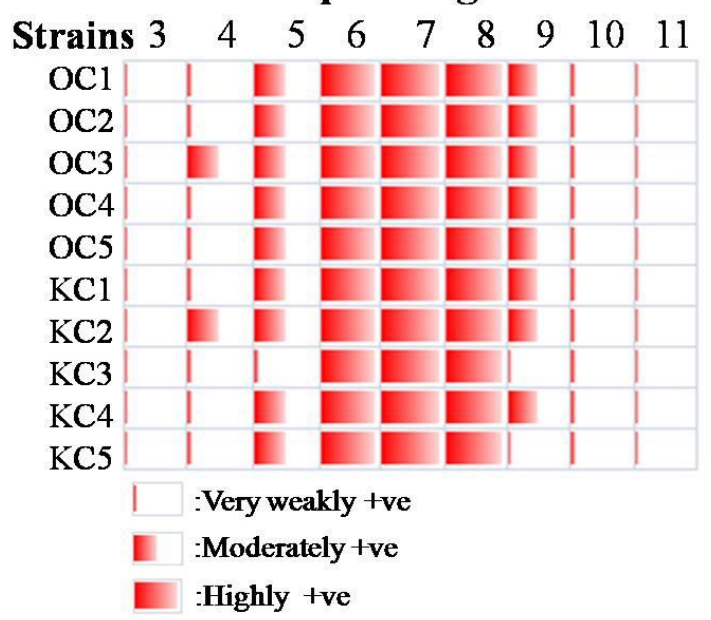

Determination of antibiotic susceptibility of the isolates

Generally, antimicrobials have been used as a primary intervention for inactivation or of pathogenic microbes in foods (Salminen, 1998). The optimization of the use of probiotic LAB for the gastrointestinal disorders requires the knowledge of their antibiotic resistance for the development of antibiotic therapy (Pan $\boldsymbol{e t} \boldsymbol{a l}$., 2009). Antibiotic resistance profile of all the isolates was studied and presented in table 2. All the isolates showed resistance to almost all the antibiotics tested. Isolates from two curd samples ( $\mathrm{OC}$ and $\mathrm{KC}$ ), five isolates from $\mathrm{OC}$ were susceptible to ampicilin, cefataxime and polymixin-B, while only two isolates; OC2 and OC5 showed sensitivity towards amphotericin$\mathrm{B}$. Among five isolates from $\mathrm{KC}$ sample, susceptibility towards polymixin-B was observed for all, where as two isolates; $\mathrm{KC} 2$ and $\mathrm{KC} 5$ showed susceptibility to amphotericin-B. Study of the antibiosis profile of the probiotics strains is one of the most promising characteristics to be used in food and food products for getting health benefits (Ahmed, 2013). Our result also showed a good agreement of antibiotic resistance ability of the strains with the previous report. Because, tolerance towards antibiotics can lead to persistency of strains inside intestinal tract but it could transfer resistance to other bacterial members through transfer of resistance gene (Mathur and Singh, 2005).

Figure 2 Physiological profile of the isolated strains from the curd samples; $\mathrm{pH}$ tolerance and salt $(\mathrm{NaCl})$ tolerance.

Table 2 Antibiotic susceptibility profile of the isolated strains showing resistance to different antibiotics

\begin{tabular}{|c|c|c|c|c|c|c|c|c|c|c|}
\hline \multirow{2}{*}{ Antibiotics } & \multicolumn{10}{|c|}{ Bacterial strains } \\
\hline & $\mathrm{OC} 1$ & OC2 & OC3 & $\mathrm{OC} 4$ & OC5 & $\mathrm{KC} 1$ & $\mathrm{KC} 2$ & $\mathrm{KC} 3$ & $\mathrm{KC} 4$ & KC5 \\
\hline Erythromycin & - & - & - & - & - & - & - & - & - & - \\
\hline Amikacin & - & - & - & - & - & - & - & - & - & - \\
\hline Polymyxin-B & + & + & + & + & + & + & + & + & + & + \\
\hline Gentamicin & - & - & - & - & - & - & - & - & - & - \\
\hline Rifampicin & - & - & - & - & - & - & - & - & - & - \\
\hline Neomycin & - & - & - & - & - & - & - & - & - & - \\
\hline Gatifloxacin & - & - & - & - & - & - & - & - & - & - \\
\hline Streptomycin & - & - & - & - & - & - & - & - & - & - \\
\hline Amoxycillin & - & - & - & - & - & - & - & - & - & - \\
\hline Amphotericin-B & - & + & - & - & + & - & - & + & - & + \\
\hline Methicillin & - & - & - & - & - & - & - & - & - & - \\
\hline Kanamycin & - & - & - & - & - & - & - & - & - & - \\
\hline Norfloxacin & - & - & - & - & - & - & - & - & - & - \\
\hline Cefactor & - & - & - & - & - & - & - & - & - & - \\
\hline Ampicillin & + & + & + & + & + & - & - & - & - & - \\
\hline Penicillin-G & - & - & - & - & - & - & - & - & - & - \\
\hline Vancomycin & - & - & - & - & - & - & - & - & - & - \\
\hline Azithromycin & - & - & - & - & - & - & - & - & - & - \\
\hline Chloramphenicol & - & - & - & - & - & - & - & - & - & - \\
\hline Cefixime & - & - & - & - & - & - & - & - & - & - \\
\hline Cefepime & - & - & - & - & - & - & - & - & - & - \\
\hline Bacitracin & - & - & - & - & - & - & - & - & - & - \\
\hline Tetracyclin & - & - & - & - & - & - & - & - & - & - \\
\hline Cephadroxil & - & - & - & - & - & - & - & - & - & - \\
\hline Cephataxime & + & + & + & + & + & - & - & - & - & - \\
\hline
\end{tabular}

Strains; OC1 to OC5 (from sample 1), KC1 to KC5 (from sample 2), +; Susceptible, -; Resistant

Test for antagonistic effect of the isolated strains/extract on enteric pathogens

Almost all the isolates showed inhibition against all the test pathogens (Table 3 ). In the spot inoculation method, highest antagonistic activity was achieved against E. coli where seven isolates (OC1, OC2, OC3, $\mathrm{KC} 1, \mathrm{KC} 2, \mathrm{KC} 4$ and $\mathrm{KC} 5)$ showed positive response. OC1, OC3, OC5, KC1, KC2 and $\mathrm{KC} 4$ (six) inhibited the growth of $S$. typhi and while OC2, OC4, KC1 and KC5 against $S$. boydii and $\mathrm{OC} 1, \mathrm{OC} 3, \mathrm{OC} 5$ and $\mathrm{KC} 2$ against E. faecalis. Among all the isolates, OC1, OC2, $\mathrm{KC} 1$ and $\mathrm{KC} 2$ demonstrated highest activity after $48 \mathrm{~h}$ of incubation. Well diffusion method showed a better result of antagonism compared to spot inoculation, where all the isolates showed inhibition against almost all the pathogen tested. $70 \%$ of them showed highest activity against E.coli and S. typhi followed by $S$. boydii and $E$. faecalis. The strain OC5 showed inhibitory action 
against all the enteric pathogens and found to be the best candidate (Table 3). But the strains OC2, OC3 (with moderate to high antagonistic activity), $\mathrm{KC} 2$ (with moderate antagonistic) were consistent among all according to both the spot and well diffusion methods. From the bacteriocin extract assay, it was observed that same strains; OC3 and $\mathrm{KC} 2$ found to be with moderate to highest antagonistic activity after 24 as well as 48 hours of incubation. However the well diffusion method of whole cell application showed a slightly better result compared to bacteriocin extract. Previous study also confirmed the similar result where the test Lactobacillus sp. members showed highest activity against E.coli followed by $S$. typhi, S. boydii and E. faecalis (Gharaei-Fathabad and Eslamifer, 2011). Our result also confirmed the similar antimicrobial property. Lactobacillus sp. members isolated from dairy and fermented dairy products also showed same type of inhibitory result against the enteropathogenic E. coli and $S$. typhi (Osuntoki et al., 2008). The antagonistic attributes could be due to production of organic acid (lactic acid, acetic acid or other acid or other metabolites) and subsequent decrease in $\mathrm{pH}$ causing inhibition of pathogen's growth. As the test strains was found to be most closely related to L. plantarum and L. brevis, the effects on enteric pathogens is quite obvious. As previous study (Morgan et al. 2009) confirmed the antagonistic potential of L. plantarum strains isolated from a probiotics food.

Table 3 Antagonistic effect of the indigenous bacterial strains and their bacteriocin extract on enteric pathogens

\begin{tabular}{|c|c|c|c|c|c|c|c|c|c|c|}
\hline \multirow[b]{2}{*}{ Pathogenic strains } & \multicolumn{10}{|c|}{ Bacterial strains (Spot inoculation method) } \\
\hline & OC1 & OC2 & OC3 & OC4 & OC5 & $\mathrm{KC1}$ & $\mathrm{KC} 2$ & KC3 & $\mathrm{KC} 4$ & KC5 \\
\hline Enterococcus fecalis & + & - & ++ & - & + & - & ++ & - & - & - \\
\hline Shigella boydii & - & ++ & - & + & - & + & - & - & - & + \\
\hline Escherichia coli & + & + & - & + & - & + & ++ & - & + & + \\
\hline Salmonella typhi & + & - & ++ & - & + & + & ++ & - & + & - \\
\hline \multirow{2}{*}{ Pathogenic strains } & \multicolumn{10}{|c|}{ Bacterial strains (Well diffusion method) } \\
\hline & $\mathrm{OC} 1$ & $\mathrm{OC} 2$ & $\mathrm{OC} 3$ & OC4 & OC5 & $\mathrm{KC} 1$ & $\mathrm{KC} 2$ & KC3 & KC4 & KC5 \\
\hline Enterococcus fecalis & + & - & ++ & - & + & + & ++ & - & + & - \\
\hline Shigella boydii & - & + & - & + & + & + & - & + & - & + \\
\hline Escherichia coli & + & - & ++ & + & + & + & - & + & - & + \\
\hline Salmonella typhi & + & + & ++ & - & + & - & ++ & - & + & + \\
\hline \multirow{2}{*}{ Pathogenic strains } & \multicolumn{10}{|c|}{ Bacteriocin extract from bacterial strains (Well diffusion method) } \\
\hline & $\mathrm{OC} 1$ & $\mathrm{OC} 2$ & OC3 & OC4 & OC5 & $\mathrm{KC} 1$ & $\mathrm{KC} 2$ & $\mathrm{KC} 3$ & $\mathrm{KC} 4$ & KC5 \\
\hline Enterococcus fecalis & + & + & ++ & - & + & - & + & - & + & - \\
\hline Shigella boydii & - & - & - & + & - & + & + & + & - & + \\
\hline Escherichia coli & + & - & ++ & - & - & + & - & + & - & - \\
\hline Salmonella typhi & + & - & ++ & + & + & - & + & - & + & - \\
\hline
\end{tabular}

Strains; OC1 to OC5 (from sample 1), KC1 to KC5 (from sample 2), +; Inhibition, ++; Moderate inhibition, -; No inhibition

\section{Amplification of 16S rRNA gene and Phylogenetic analysis}

$16 \mathrm{~S}$ ribosomal ribonucleic acid (rRNA) analysis and sequencing is one of the measure current methodologies, on which classification of LAB mainly rely on (Rauta et al., 2013; Drancourt et al., 2000). Among all the bacterial isolates, OC3 and KC2 showed positive response in all the studied properties and hence were selected for identification and phylogenetic analysis by partial $16 \mathrm{~S}$ rRNA gene sequence based method. The genomic species level identification was defined as a $16 \mathrm{~S}$ rDNA sequence similarity above $99 \%$ with the query sequence (Murray et al., 2009). A total of 1370 nucleotide stretch of 16S rRNA gene for strain KC2 and 1404 nucleotide stretch for OC3 were obtained after the sequencing. Based on these partial sequences, BLASTn search was performed and $\mathrm{KC} 2$ showed $99 \%$ (with $100 \%$ query coverage) identity match with Lactobacillus plantarum strains (accession: KP345895, KP230423, KM982988 and KP178090). While, OC3 showed 99\% (with 99\% query coverage) similarity with Lactobacillus brevis strain (accession: AB626062, AB024299, KP889228 and LC062897). All the strains showed maximum sequence homology with Lactobacillus sp. members. Hence, the type strains of genus Lactobacillus were retrieved from RDP database and aligned with the sequence of both the strains by both pairwise and multiple alignment and phylogenetic dendrogram tree was constructed by neighbor joining (NJ) algorithm of Jukes-Cantor by MEGA 5.1. Based on phylogeny, the tree showed close taxonomic relatedness of the strain $\mathrm{KC} 2$ with the clade containing the type strains including L. xiangfangensis 3.1.1. (Isolated from Chinese pickle), L. fabifermentans LMG 24284 (cocoa fermentation), L. paraplantarum DSM 10667 (fermented beer), L. plantarum DK022 and L. plantarum NRRLB-14768 (Korean kimchi) having 100\% bootstrap value. OC3 was claded with L. brevis ATCC 14869 type strain with $100 \%$ bootstrap value showing close taxonomic affiliation to Lactobacillus sp (Figure 3). The same tree was also inferred from maximum-likelihood method for confirmation of robustness of the tree (data not shown). Interestingly it was observed that, the test strains ( $\mathrm{KC} 2$ and $\mathrm{OC} 3$ ) showed close taxonomic relatedness with the Lactobacillus sp isolated from different fermented foods and confirmed its relationship, as the strains have also been isolated from fermented milk product (curd). The present results corroborates with the previous findings (Jagadeswari et al., 2010; Shantnya et al., 2011) demonstrating isolation of Lactobacillus plantarum, Lactobacillus casei, Lactobacillus brevis and Lactobacillus acidophilus from raw goat milk.

\section{Genebank accession number}

The partial 16S rRNA gene sequences of the strains KC2 and OC3 were isolated and deposited in the GeneBank (http://www.ncbi.nlm.nih.gov/genbank/) and under the following accession number KT380050 and KT380051.

\section{Growth behavior study of the selected bacterial strains}

The strain $\mathrm{KC} 2$ and $\mathrm{OC} 3$ were selected for study of growth behavior and kinetics as they performed well in all the experiments. Both the strains showed almost similar growth pattern showing very less (around $1 \mathrm{hr}$ ) lag phase (Figure 4) Multiplication of cells in logarithmic phase started from $2 \mathrm{hrs}$ and persisted up to $12 \mathrm{hrs}$. Although, both the strains showed similar multiplication rate at initial log phase but after $6 \mathrm{hrs}$, showed slight divergence in growth rate (Figure 4). The end of logarithmic phase was noticed with the final OD of around 1.6. Growth rate ( $\mu$ ) was calculated and found to $0.42 \mathrm{~h}^{-1}$ for $\mathrm{KC} 2$ and $0.32 \mathrm{~h}^{-1}$ for $\mathrm{OC} 3$ showing high growth rate of $\mathrm{KC} 2$ compared to $\mathrm{OC} 3$. But, interestingly for the strain OC3, stationary phase persisted for a long time while, death phase was noticed for the strain KC2 followed by short stationary phase. Compared to test strains, E.col (internal control) showed a slow growth rate $\left(\mu=0.2 \mathrm{~h}^{-1}\right)$, with a long lag phase of 5-6 hrs. In log phase, highest OD achieved was found to be 0.8 , just half of the OD obtained for test strains. While blank showed no significant increase in turbidity and hence OD, confirming its sterility. The growth behavior noticed in this study coincided with the growth characteristics of Lactobacillus sp. obtained in previous study (Asha and Gayatri, 2012; Brizuela et al., 2001) confirming the growth rate of Lactobacillus sp. to be around $0.5 \mathrm{~h}^{-1}$. Since Lactobacillus species are involved in a large number of spontaneous food fermentation and processing and also inevitable for the human health, Use of such organism as probiotics is a good choice for human health. In the present study, two Lactobacillus sp. (OC3 and $\mathrm{KC} 2$ ) affiliated to L. paraplantarum and L. brevis showed broad antibiotic resistance with antimicrobial activity agains pathogenic microorganisms, tolerance to wide $\mathrm{pH}$, salt $(\mathrm{NaCl})$ concentrations were obtained. These strains can be used as starter inoculum for fermented dairy products and as potential probiotics agents. 


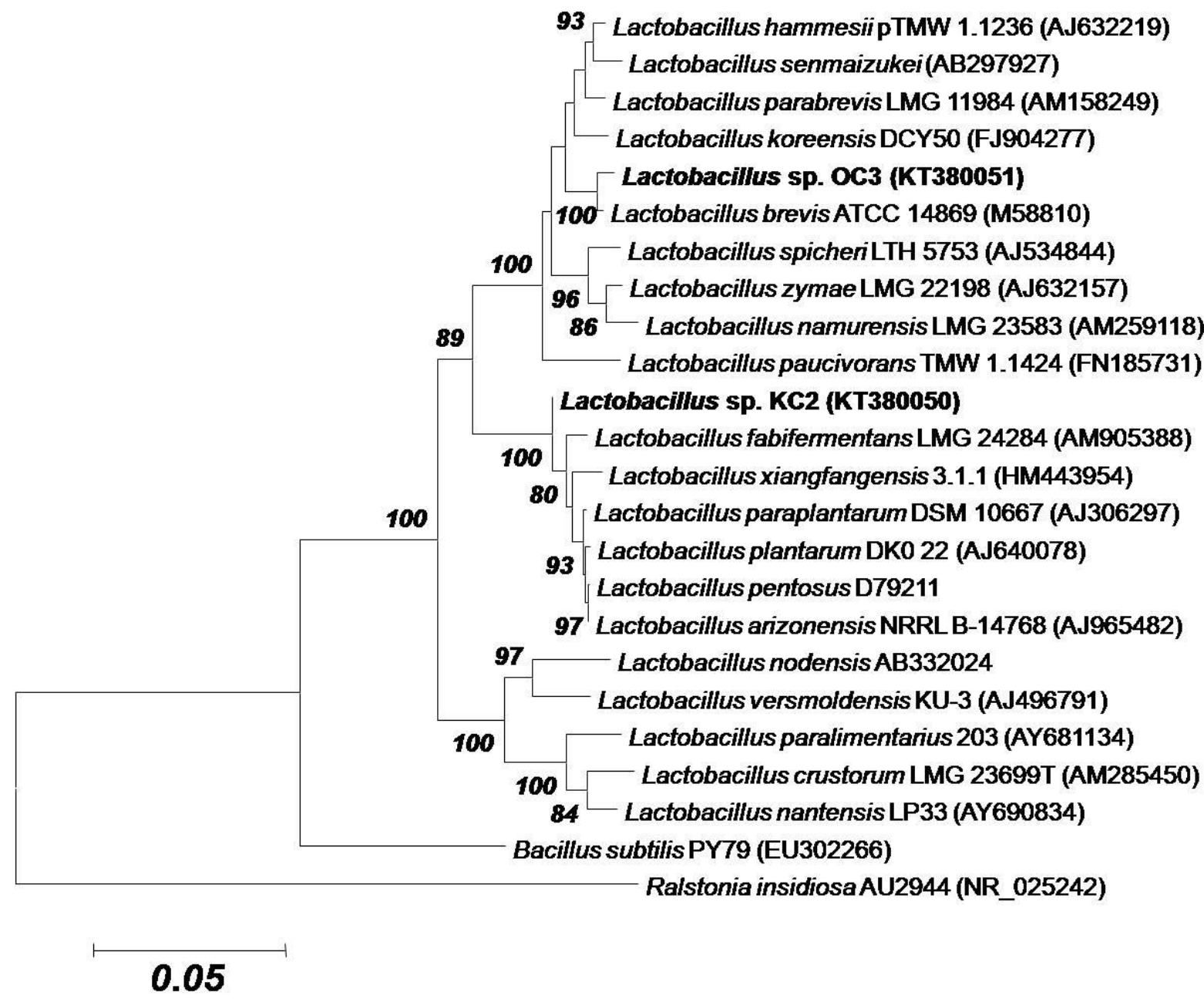

Figure 3 Neighbor-joining phylogenetic tree based on 16S rRNA gene sequence of two selected strains; OC3 and KC2 with type strains of closely related species within the genus Lactobacillus. The significance of each branch is indicated by a bootstrap value calculated for 1000 replications. Represented type strains of the Lactobacillus sp. and outgroup is presented along with the test strains. Bootstraps of above $70 \%$ are shown at each branch points. GenBank accession number of $16 \mathrm{~S}$ rRNA gene sequences of each strain is in parentheses. Bar 0.05 indicates 5\% nucleotide substitution.

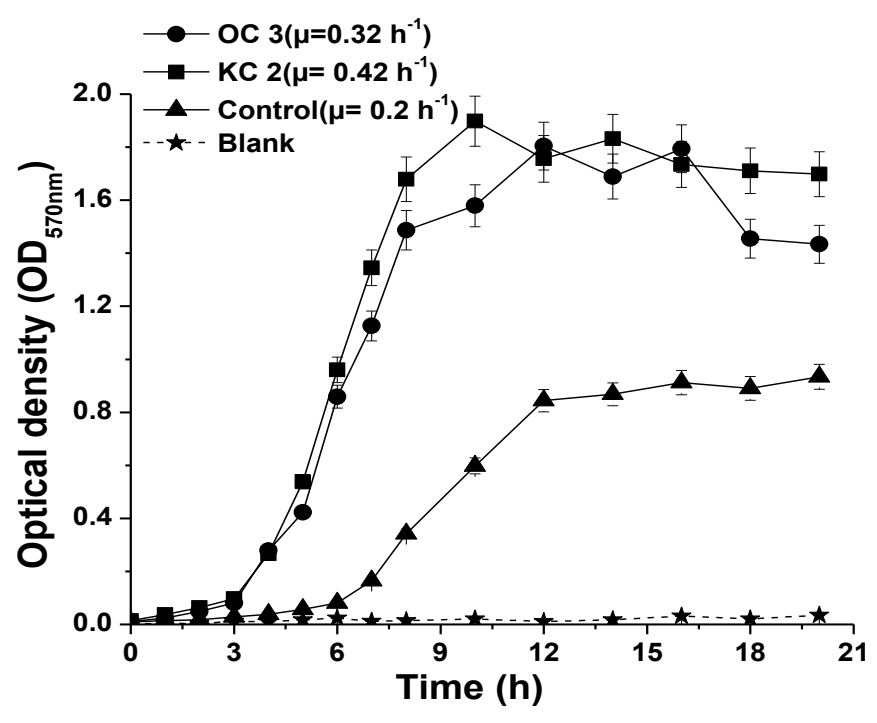

Fig 4 Growth profile of the bacterial strains; OC3 and KC2 in MRS broth medium, where E. coli was taken as internal control. Specific growth rate $(\mu)$ has been calculated and mentioned in parentheses. Error bar indicates standard deviation, where $n=3$.

\section{CONFLICT OF INTEREST}

No conflict of interest declared.
Acknowledgement: The authors are grateful to the Department of Microbiology, Centre for Post-graduate Studies (CPGS), Orissa University of Agriculture and Technology, Bhubaneswar- 751003, Odisha, for providing financial support and necessary research facilities. All the authors are also grateful to Mr. Pradipta Ranjan Rauta, Researcher, Immnunology and Molecular Medicine Laboratory, Department of Life Sciences, National Institute of Technology, Rourkela (Odisha), 769008, India for his valuable suggestions and necessary comments for improving the manuscript

\section{REFERENCES}

Ahmed, A. A. (2013). In vitro Screening of Lactobacillus species from Homemade Yoghurt for Antagonistic Effects against Common Bacterial Pathogens. Jord. J. Biol Sci, 6, 211-216. http://dx.doi.org/10.12816/0001535

Asha, Gayathri, D. (2012). Antagonistic Potential of Lactobacillus Spp against Enteropathogenic Bacteria; Purification and Characterization of their Bacteriocins. Adv. J. Food Sci Technol, 4, 265-269.

Ballal, M., Shivananda, P. G. (2002). Rotavirus and enteric pathogens in infantile diarrhoea in Manipal, South India. Indian. J. Pediatr, 69, 393-396. http://dx.doi.org/10.1007/bf02722628

Bauer, A. W., Kirby, W. M. M., Sherris, J. C., Twick, M. (1966). Antibiotic susceptibility testing by a standardized single disk method. Am. J. Clin. Pathol, 45, 493-496. http://dx.doi.org/10.1007/978-1-4613-3159-9_6

Brizuela, M. A., Serrano, P., Pérez, Y. (2001). Studies on Probiotics Properties of Two Lactobacillus Strains. Braz. Arch. biol technol, 44, 95-99. http://dx.doi.org/10.1590/s1516-89132001000100013

Chan, W., Boswell, C., Zhang, Z. (2000). The effect of different in-vitro solutions in the dissolution of calcium pectinate beads intended for the delivery of live cells to the human large intestine. Minerva Biotechnol, 12, 271-278.

Chowdhury, A., Hossain, M. N., Jannatul, N. (2012). Screening of Lactobacillus spp. from Buffalo Yoghurt for Probiotic and Antibacterial Activity. J. Bacteriol Parasitol, 3, 1-5. http://dx.doi.org/10.4172/2155-9597.1000156 
Cleveland, J., Montville, T. J., Nes, I. F., Chikindas, M. L. (2001). Bacteriocins: safe, natural antimicrobials for food preservation. Int. J. Food Microbiol, 71, 120. http://dx.doi.org/10.1016/s0168-1605(01)00560-8

Davidson PM, Zivanovic S (2003). Food antimicrobials. Vol. I, pp. 1-10. In Antimicrobials in foods. Davidson PM, Sofos JN, Branen AL (ed). CRC press, Inc., FL, USA. http://dx.doi.org/10.1201/9781420028737

Delves-Broughton, J., Blackburn, P., Evans, R. J, Hugenholtz, J. (1996). Application of the bacteriocin, nisin. Antonie van Leeuwenhoek, 69, 193-202. http://dx.doi.org/10.1007/bf00399424

Drancourt, M. C., Bollet Carlioz, A. (2000). 16S ribosomal DNA sequence analysis of a large collection of environmental and clinical unidentifiable bacterial isolates. J. Clin. Microbiol, 38, 3623-3630. http://dx.doi.org/10.1128/jcm.39.7.2425-2430.2001

Dunne, C., O’Mahony, L., Murphy, L., Thornton, G. et al. (2001). In vitro selection criteria for probiotic bacteria of human origin: correlation with in vivo findings. Ame. J. Clin Nutr, 73, 386-392. http://dx.doi.org/10.1016/s00165085(00)85238-5

Felis, G. E, Dellaglio, F. (2015). Taxonomy of Lactobacilli and Bifidobacteria. Curr Issues Intestinal Microbiol, 8, 44-61. http://dx.doi.org/10.1007/978-0-38779058-9 15

Forouhandeh, H., Vahed, S. Z, Hejazi, M. S, Nahaei, M. R, Dibavar, M. A (2010). Isolation and phenotypic Characterization of Lactobacillus species from various dairy products. Curr Res Bacteriol, 3, 84-88. http://dx.doi.org/10.3923/crb.2010.84.88

Gharaei-Fathabad, E., Eslamifar, M. (2011). Isolation and Applications of one strain of Lactobacillus paraplantarum from tea leaves (Camellia sinensis). Am. J. Food Technol, 6, 429-434. http://dx.doi.org/10.3923/ajft.2011.429.434

Holt, J. G, Krieg, N. R, Sneat, P. H. A., Staley, J. T., Williams, S. T. (1994) Bergey's manual of determinative bacteriology. 9th ed. Lippincott Williams and Wilkins Philadelphia, Pennsylvania, USA. http://dx.doi.org/10.1099/0022261511-2-219a

Holzapfel, W. H., Geizen, R., Schillinger, U. (1995). Biological preservation of foods with reference to protective cultures, bacteriocins and food grade enzyme Int. J. Food Microbiol, 24, 343-362. http://dx.doi.org/10.1016/0168 1605(94)00036-6

Jagadeswari, S., Vidya, P., Kumar, D. J. M., Balakumaran, M. D. (2010) Isolation and characterization of bacteriocin producing Lactobacillus sp from traditional fermented foods. Electronic j Environ. Agric Food Chem, 9, 575-581. http://dx.doi.org/10.1016/s0944-5013(00)80006-3

Kyriacou, A., Tsimpi di, E., Kazantzi, E., Mitsou, E. et al. (2008). Microbial content and antibiotic susceptibility of bacterial isolates from yoghurts. Int. J. Food Sci Nutr, 59, 512-525. http://dx.doi.org/10.1080/09637480701565729

Mathur, S., Singh, R. (2005). Antibiotic resistance in food lactic acid bacteria--a review. Int. J. Food Microbiol, 105, 281-295. http://dx.doi.org/10.1016/j.ijfoodmicro.2005.03.008

Mobarez, A. M., Hosseini Doust, R., Sattari, M., Mantheghi, N. (2008). Bacteriocin like substance produced by $L$. acidophilus from traditional yoghurt on P.aeruginosa and $S$. aureus. J. Biol Sci, 8, 221-224. http://dx.doi.org/10.3923/jbs.2008.221.224

Morgan, M. C, Boyette, M., Goforth, C., Katharine, V. S, Shermalyn, R. (2009). Comparison of the Biolog OmniLog Identification System and 16S ribosomal RNA gene sequencing for accuracy in identification of atypical bacteria of clinical origin. Greece J. Microb. Meth, 79, 336-343. http://dx.doi.org/10.1016/j.mimet.2009.10.005

Murry, A. C. Jr., Hinton, A. Jr., Morrison, H. (2004). Inhibition of growth of Escherichia coli, Salmonella typhimurium and Clostridium perfringens on chicken feed media by Lactobacillus salivarius and Lactobacillus plantarum. Int J Poult Sci, 3, 603-607. http://dx.doi.org/10.3923/ijps.2004.603.607

Osuntoki, A. A, Ejide, O. R., Omonigbehin, E. A. (2008). Antagonistic effects on Enteropathogenic and plasmid analysis of Lactobacilli isolated from fermented $\begin{array}{llll}\text { Dairy } & \text { products. } & \text { Biotechnology, } & \text { 311-316 }\end{array}$ http://dx.doi.org/10.3923/biotech.2008.311.316

Pan, X., Chen, F., Wu, T., Tang, H., Zhao, Z. (2009). The acid, bile tolerance and antimicrobial property of Lactobacillus acidophilus. Int. J. Food Control, 20 598-602. http://dx.doi.org/10.1016/j.foodcont.2008.08.019

Parada, J. L., Caron, C. R., Madeiros, A. B. P., Soccol, C. R. (2007) Bacteriocins from Lactic Acid Bacteria: Purification,Properties and use as Biopreservatives. Braz. Arch. Biol Technol, 50, 521-542. http://dx.doi.org/10.1590/s1516-89132007000300018

Puniya, M., Sangu, K. P. S., Bhardwaj, A., Gupta, D., Kumar, S., Dhewa, T. Pant, S. (2012). Probiotic and Functional Attributes of Lactobacillus Spp Isolated From Human Faeces. J. Res Antimicrob, 1, 001-011. http://dx.doi.org/10.1007/s11274-010-0494-4

Pyar, H., Peh, K. K. (2014). Characterization and identification of lactobacillus acidophilus using biolog rapid identification system. Int. J. Pharm Pharm Sci, 6, 189-193. http://dx.doi.org/10.3923/ijp.2013.92.97

Rauta, P. R., Dhupal, M., Nayak, B. (2013). Screening and characterization of potential probiotic lactic acid bacteria isolated from vegetable waste and fish intestine. Int. J. Curr. Microbiol. App. Sci, 2, 234-244.
Salminen, S. A., Von Wright, L., Morelli, P., Marteau, D., Brassart, W. M., De Vos, R., Fonden. M. (1998). Demonstration of safety of probiotics a review. Int J. Food Microbiol, 44, 93-106. http://dx.doi.org/10.1016/s0168-1605(98)00128-7 Shanthya, R., Saranya, S., Shenpagam, H. (2011). Antagonistic effects of Lactobacilli on gram negative bacteria. J. Adv. Lab Res Biol, 2, 86-89. http://dx.doi.org/10.1111/j.1365-2672.2006.02963

Tagg, J. R., Dajani, A. S., Wannamaker, L. W. (1976). Bacteriocins of Grampositive bacteria. Bacteriol Rev, 40, 722-756. http://dx.doi.org/10.1007/978-3540-36604-1_4 